\title{
Extraction of Pectin from Breadnut Fruit (Artocarpus altilis Fosberg.) with Citric Acid
}

\author{
Daris Ardiansyah ${ }^{1}$, Ismiarni Komala ${ }^{2 *}$, Zilhadia $^{3}$ \\ \{daris.ardiansyah15@mhs.uinjkt.ac.id¹,ikomala@uinjkt.ac.id², zilhadia@uinjkt.ac.id³ \\ *corresponding author
}

Pharmacy Department, Faculty of Health Sciences, UIN Syarif Hidayatullah Jakarta, Jakarta. Jl. Kertamukti, Pisangan, Ciputat, Indonesia ${ }^{1,2,3}$

\begin{abstract}
Pectin is a complex polysaccharide that is found in the primary cell wall of higher plants. Pharmaceutically, pectin has been used as a gelling agent, thickener, stabilizer emulsifier, and edible coating in the food industry. The purpose of this study was to extract and characterize the isolated pectin from breadnut fruit (Artocarpus altilis Fosberg). Extraction was conducted by using $1 \%$ citric acid ( $\mathrm{pH}$ adjusted to 2 , temperature $90^{\circ} \mathrm{C}$ ) in the variation of times ( 2 and 3 hours). Furthermore, the yield and characteristics of pectin were evaluated statistically. The results showed that no significant differences in yield, water content, ash content, equivalent weight, and degree of esterification of pectin when extraction was conducted at different times ( 2 and 3 hours). Variation time of extraction only showed a significant effect on the methoxyl contents and galacturonic acid contents of pectin.
\end{abstract}

Keywords: Artocarpus altilis Fosberg, breadnut, characteristics of pectin, extraction.

\section{Introduction}

Gelatin is one of the multifunctional biopolymers in both the food industry and the pharmaceutical industry, which until now has problems in terms of halal. The problem lies in the majority of gelatin raw material is $46 \%$ are source from pigskin. The gelatin from cowhide is only about $29.4 \%$ and is rarely used by industry in the manufacturing process, due to its higher price compared to pork gelatin [1].

Several attempts have been made to respond to problems related to the use of pork gelatin. Besides continuing to look for halal sources of gelatin, research is also directed to look for other biodegradable polymers that can replace the function of gelatin, or called gelatin replacer. One of the known plant-based gelatin replacers is pectin [2].

Pectin can be used as an alternative to gelatin which is relatively easy to obtain and its cost-effectiveness is also high. This is because pectin can easily be obtained through the extraction process from fruit waste that is not used in the manufacturing process. Commercial pectin that can be found today is almost exclusively obtained from orange peels or apple pomace, both of which are wasted from manufacturing juice products. The pulp of apples containing pectin $10-15 \%$ of the total dry base. Orange peel contains relatively higher pectin which is around $20-30 \%$. Alternative sources of pectin include sugarbeet waste obtained from the sugar manufacturing process, sunflower heads, and mango waste [2], [3].

Breadnut is a close relative to breadfruit (both are known as Kluwih and Suku in Indonesia, respectively). Which can also be used as a source of pectin. Breadnut comes naturally from Indonesia, especially the Maluku islands, as well as Papua New Guinea, besides this fruit can also be found in the Philippines. Compared to some other species of Artocarpus, the 
breadnut is not very well known by the community, besides that the fruit is still not fully utilized. Indonesian people and the Philippines in general use breadnut to be processed into stew and vegetable dishes, due to their high nutritional content [4]-[6].

Previous studies related to pectin from breadnut fruit were able to find out that the content of pectin in breadnut fruit was $1.95 \%$. Pectin is obtained by conventional extraction using hydrochloric acid ( $\mathrm{pH} 1.5-2)$, for 4 hours at $80^{\circ} \mathrm{C}$ [5]. However, this study has not yet evaluated the characteristics of the pectin obtained, and also not yet known the factors that can affect the characteristics of pectin.

As a follow-up, this study will examine variations in the extraction time of the conventional methods on the yield and characteristics of pectin extracted from breadnut fruit with citric acid solvents. Citric acid was chosen because it is more environmentally friendly when compared to mineral acids [7]. This study also conducted an Alcohol Insoluble Residue preparation in advance aimed at increasing the purity of the pectin obtained [8]. Statistical analysis was also applied in this study to assess the significance of the tested variables.

\section{Method}

\subsection{Materials.}

The materials were the whole fruits of breadnut (Artocarpus altilis Fosberg) obtained from Bogor, West Java, Indonesia (September 2019) and determined at Bogoriense Herbarium, LIPI Biology Research Center, Cibinong, West Java, Indonesia. Citric acid was purchased from PT. Smart-Lab, Indonesia. Hydrochloric acid (analytical grade; Merck) and phenolphthalein indicator (technical grade) was purchased from Rofa Laboratorium Center, Indonesia.

\subsection{Instrumentation.}

A Jasco FT/IR-6100 spectrophotometer was used to analyze the infrared spectrum of pectin.

\subsection{Procedure}

Preparation of alcohol insoluble residue (AIR). The materials were washed with flowing water, then chopped into small pieces, the results were then heated in ethanol $96 \%$ (solid-solvent ratio $1: 2 \mathrm{w} / \mathrm{v}$ ) at $80^{\circ} \mathrm{C}$ for 15 minutes and continue to dry. The dried materials were then ground into powders and then sieved with a 20 mesh size. [9], [10]. The powder materials were then heated in ethanol $80 \%$ (solid-solvent ratio $1: 4 \mathrm{w} / \mathrm{v}$ ) at $80^{\circ} \mathrm{C}$ for 45 minutes in an Erlenmeyer flask on a hot-plate, further filtered, and then washed three times with ethanol $60 \%$ and followed with ethanol $96 \%$ and allowed to dry at room temperature until completely dry [9].

Pectin extraction. The AIRs were heated in the citric acid solvent at $\mathrm{pH} 2$ with a solid-extractant ratio of 1:15 (w/v). The extraction process was carried out three times by heating the AIRs at $90^{\circ} \mathrm{C}$ for 2 hours, and 3 hours on a hot plate. The extraction result was filtered in a hot state with a cotton cloth. The filtrate obtained is called pectin filtrate [9], [11]-[13]. Ethanol 96\% was added to the filtrate with a ratio of $1: 1 \mathrm{v} / \mathrm{v}$, the mixture was allowed to stand for 12 hours to let the pectin be precipitated. The pectin precipitates were filtered with a cotton cloth, and then washed twice with ethanol $70 \%$ and once with ethanol $96 \%$. After that, the wet pectins were dried in the oven at $40^{\circ} \mathrm{C}$ for at least 12 hours until the pectin completely dry [9].

The yield of pectin. The yield of pectin was calculated with equation (1) below:

$$
\text { Yield }(\%)=(\mathrm{W} 2 / \mathrm{W} 1) \times 100
$$


The W2 was defined as the weight of pectin obtained, while W1 was defined as the weight of the AIR powders [9].

\section{Evaluation of pectin's characteristics.}

The pectin characteristic evaluation carried out in this study included: organoleptic, moisture content [14], Ash content. [15], Equivalent weight (EW) [16], Methoxyl (MeO) content of pectin. [16], Galacturonic Acid (GA) content of pectin. [16], Degree of esterification (DE) of pectin. [17].

\section{FTIR analysis.}

The Pectin powders were mixed with $\mathrm{KBr}$ with a ratio of 1:100. FT/IR 1600 spectrophotometer (Jasco, Japan) was applied for analysis at absorbance mode in the wavenumber of $4000-400 \mathrm{~cm}^{-1}[18]$.

\section{Results}

Table 1. The yield of the pectin.

\begin{tabular}{lc}
\hline Sample & Mean $\pm \mathbf{S D ~}(\mathbf{\%})$ \\
\hline $\mathrm{A}$ & $6,80 \pm 0,76^{\mathbf{a}}$ \\
$\mathrm{B}$ & $7,36 \pm 0,46^{\mathbf{a}}$ \\
\hline Note: A; 2 hours of extraction time, B; 3 hours of extraction time, n; the number of \\
replications, and SD; the standard of deviation; Value in the same column with no \\
different superscript letters was not significantly different ( $\mathrm{p}>0,05)$. \\
\hline
\end{tabular}

Table 2. The organoleptic of pectin

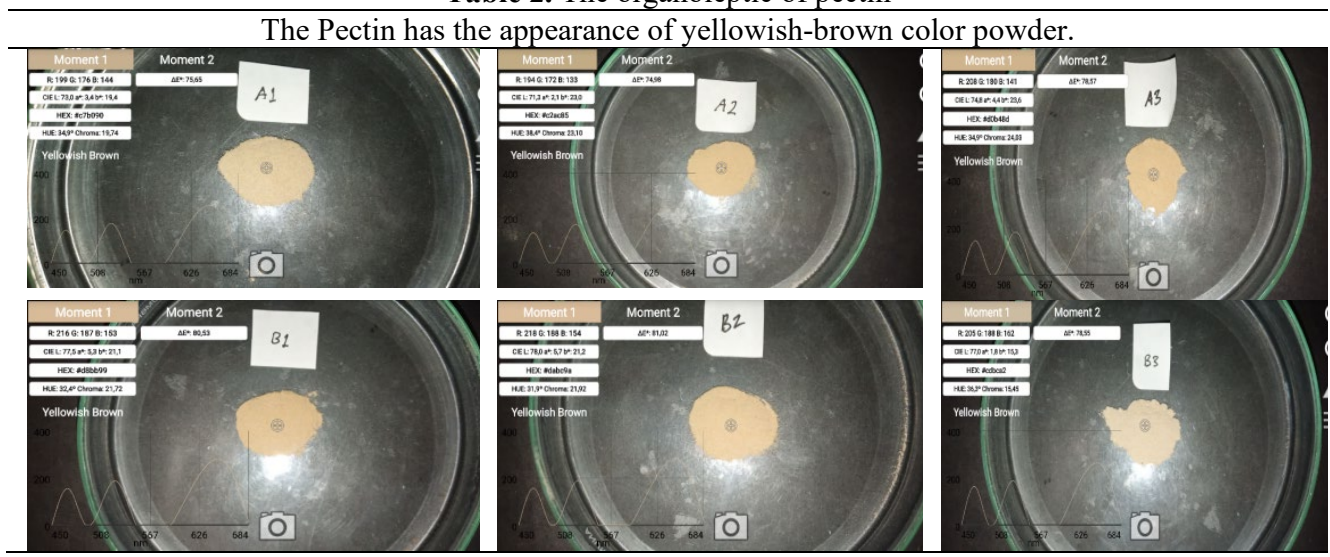


Table 3. The physicochemical characteristics of pectin.

\begin{tabular}{|c|c|c|c|c|c|}
\hline \multirow[b]{2}{*}{ No. } & \multirow[b]{2}{*}{ Characteristics } & \multicolumn{2}{|l|}{ Mean ( \pm SD) } & \multicolumn{2}{|c|}{ Requirements } \\
\hline & & $\mathbf{A}$ & B & IPPA & $\begin{array}{l}\text { FI V } \\
\text { dan } \\
\text { USP 32 } \\
\end{array}$ \\
\hline 1. & $\begin{array}{l}\text { Moisture content } \\
(\%)\end{array}$ & $12.06( \pm 0.61)^{\mathrm{a}}$ & $11.24( \pm 0.91)^{\mathrm{a}}$ & $<12 \%$ & $<10 \%$ \\
\hline 2. & $\begin{array}{l}\text { Total ash content } \\
(\%)\end{array}$ & $3.28( \pm 0.05)^{\mathrm{a}}$ & $3.10( \pm 0.13)^{\mathrm{a}}$ & - & - \\
\hline 3. & $\begin{array}{l}\text { Equivalent weight } \\
(\mathrm{g} / \mathrm{Eq})\end{array}$ & $\begin{array}{l}2134.46( \pm \\
88.58)^{\mathrm{a}}\end{array}$ & $\begin{array}{l}2407.06( \pm \\
168.58)^{\mathrm{a}}\end{array}$ & - & - \\
\hline 4. & $\mathrm{MeO}$ content $(\%)$ & $1.27( \pm 0.10)^{\mathrm{a}}$ & $0.93( \pm 0.13)^{\mathrm{b}}$ & - & $\geq 6.7 \%$ \\
\hline 5. & GA content $(\%)$ & $15.57( \pm 0.69)^{\mathrm{a}}$ & $12.61( \pm 0.87)^{b}$ & $\geq 65 \%$ & $\geq 74 \%$ \\
\hline 6. & $\mathrm{DE}(\%)$ & $46.55( \pm 2.21)^{\mathrm{a}}$ & $41.77 \pm 4.12)^{\mathrm{a}}$ & - & - \\
\hline $\begin{array}{l} \\
\end{array}$ & $\begin{array}{l}2 \text { hours of extractio } \\
\text { A; International Pec } \\
\text { tes Pharmacopoeia. } \\
\text { mean based on thre } \\
\text { lue in the same rov } \\
0,05 \text { ). }\end{array}$ & $\begin{array}{l}\text { me, B; } 3 \text { hours } \\
\text { Producer Associa } \\
\text { me replication } \\
\text { ith no different }\end{array}$ & $\begin{array}{l}\text { extraction time, } \\
\text { n, SD; the standa } \\
\text { uperscript letters }\end{array}$ & $\begin{array}{l}\text { donesia } \\
\text { leviation } \\
\text { not sign }\end{array}$ & $\begin{array}{l}\text { acopoeia, } \\
\text { SP; United } \\
\text { different }\end{array}$ \\
\hline
\end{tabular}

\section{Discussion}

The extraction of pectin from breadnut fruit in variation time 2 and 3 hours gave a yield of $6.80 \pm 0.72 \%$ and $7.36 \pm 0.46 \%$, respectively. Variation of time was not statistically significant $(\mathrm{p}>0.05)$ in the yield obtained (Table 1). The yield of pectin in this study is higher than previous studies that extracted pectin from breadnut fruit using hydrochloric acid $(\mathrm{pH} 1.5$ - 2). [5]. The use of citric acid as a solvent in the extraction process can minimize the degradation of the backbone of pectin, so that the pectin obtained can have a higher molecular weight, and is easily precipitated by ethanol $96 \%$ [19].

The process of extracting pectin from breadnut fruit produced pectin with a yellowishbrown color, both in sample A and sample B (Table 2). Some pectin from previous studies had relatively similar organoleptic after extraction using a similar method using citric acid solvents [20]. IPPA describes pectin as white, yellowish, light grayish, light brown, or light brown powder [21], [22]. While Indonesian pharmacopeia and USP 32 describe pectin as a coarse or fine powder with a yellowish-white color, odorless, and has a taste like mucilage [14], [23].

The difference in the extraction time ( 2 hours and 3 hours) did not significantly affect the moisture content of pectin Breadnut fruit. Low moisture content was preferred because it could inhibit the growth of microorganisms. Contamination of microorganisms in pectin could cause pectin polymer decomposition, caused by the accumulation of the pectinase enzyme. Indonesian Pharmacopeiae 5 and USP 32 has required pectin moisture content of not more than $10 \%$ [14], [23]. While IPPA has required pectin water content of no more than $12 \%$. So it can be concluded that the water content of the breadnut fruit pectin in this study better meets the requirements of pectin determined by IPPA [21].

Low ash content $(<10 \%)$ was required to obtain pectin with a good gelling ability [8]. Several factors that can affect the ash content in pectin are the nature of raw materials, extraction 
procedures, and pectin isolation procedures. Mineral content in raw materials could have an impact on the ash content of the pectin obtained. The more mineral content in the form of calcium and magnesium in the raw material, the higher the ash content in pectin [24]. Efforts could be made to reduce ash content in pectin, including by washing pectin isolates with acidified alcohol, or by extracting pectin using solvents that can bind metals, one of which is sodium hexametaphosphate [13]. In this study, the ash content was not significantly affected by the extraction time $(\mathrm{p}>0.05)$. In several previous studies, it has been reported that increasing the extraction time could have an impact on increasing ash content in pectin. This was due to the increased accumulation of calcium and magnesium minerals as a result of the hydrolysis of the calcium-magnesium pectate complex in the cell matrix [25].

The extraction time did not have a significant effect on the equivalent weight of the pectin produced $(\mathrm{p}>0.05)$. High equivalent weight could indicate a low partial degradation that occurs in the pectin polymer chain [26]. the equivalent weight could be influenced by plant species, nature/quality of raw materials, and the extraction methods used [26]. One of the properties of raw materials that can affect the equivalent weight of pectin is the level of maturity. The equivalent weight of the pectin is higher when compared to the equivalent weight of commercial pectin used as a comparison in several studies. In one study, commercial pectin from the orange peel with an equivalent weight of $445.59 \mathrm{~g} / \mathrm{Ek}$ was used [27]. While in some other studies used commercial pectin from orange peel and applesauce pulp which both have an equivalent weight of $893 \mathrm{~g} / \mathrm{Eq}$ [28], [29]. Commercial pectin is generally extracted using a hydrochloric acid solution, so that most of the pectin obtained has a low molecular weight, due to its higher ionization strength when compared with the citric acid used in this study [7], [30].

The difference in the extraction time gave a significant effect on the $\mathrm{MeO}$ contents of the pectin $(\mathrm{P}<0.05)$ (see table 4). Increasing the extraction period tends to reduce the $\mathrm{MeO}$ contents of pectin because pectin has a longer demethylation process [31]. The process of demethylation by acids can occur under low $\mathrm{pH}$ conditions, below or in the range of $\mathrm{pKa}$ pectin (at $\mathrm{pH} 3.5)$ [32]. The pectin produced in this experiment is classified as low methoxyl pectin because its methoxyl levels are below 7\% [33]. Low methoxyl pectin could form a gel with the help of divalent cations, usually, calcium $\left(\mathrm{Ca}^{2+}\right)$, the process of forming this gel does not depend on much sugar added to the formula.

GA contents were an indicator to assess the level of purity of pectin. IPPA required GA contents from commercial pectin to be not less than $65 \%$, while Indonesian pharmacopeia and USP required GA levels of not less than 74\% [21], [23]. The extraction time significantly affected the GA contents of the pectin $(\mathrm{p}<0.05)$. In another study, pectin from soy hull, passion fruit peel, and orange pomace had a galacturonic acid content of $18.85 \%, 23.21 \%$, and $16.01 \%$, respectively [34]. The low GA contents might be caused by the number of non-uronate components, such as starch, protein, and free sugars that are extracted along with the longer extraction process. The non-uronate component could interfere with the determination of GA by the alkalimetric titration method [8].

Pectin with a DE value above $50 \%$ is expressed as high-methoxyl pectin, while pectin with a value below $50 \%$ is expressed as low-methoxyl pectin [30]. The pectin obtained in this study was categorized as low methoxyl pectin. The extraction time did not significantly affect the $\mathrm{DE}$ of the breadnut fruit pectin $(\mathrm{P}>0.05)$. The $\mathrm{DE}$ of pectin can gradually decrease with the length of the extraction process. This is because the contact between the pectin molecule and the longer solvent can accelerate the de-esterification process [35]. The IR spectrum of breadnut (Figure 2) showed similarities in shape and bands with the standard pectin IR spectra [36]. 

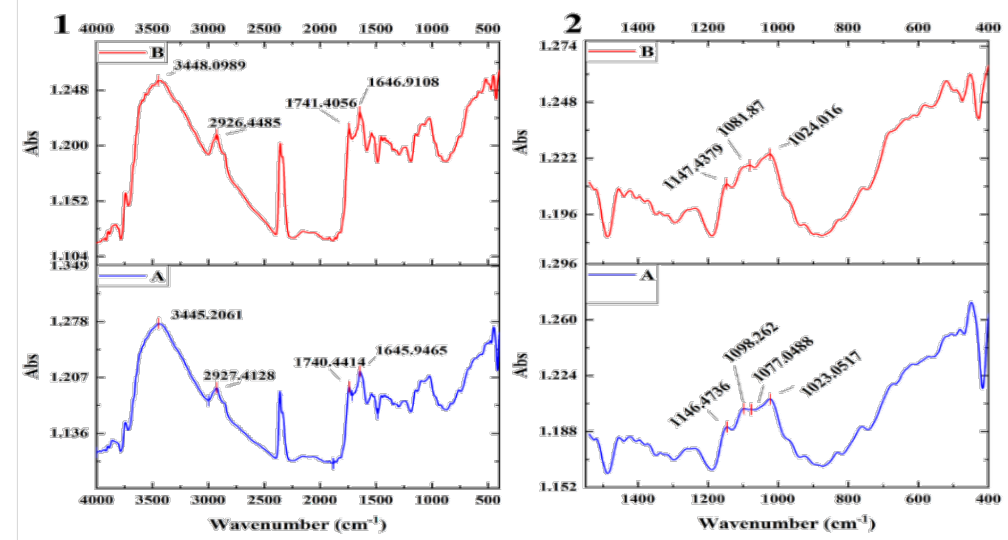

Fig. 1. FTIR spectrum of breadnut fruit pectin at $4000-400 \mathrm{~cm}^{-1}(1)$ and magnification at fingerprint area (2). The blue line was the spectrum of sample A (2 hours of extraction times), and the red line was the spectrum of sample B (3 hours of extraction time).

\section{Conclusion}

The results of this study indicate that differences in the extraction time range did not significantly influence the yield of breadnut fruit, and the characteristics of pectin which include moisture content, ash content, equivalent weight, and degree of esterification (DE). However, it has a significant impact on the brightness level of breadnut pectin powder and physicochemical properties such as galacturonic acid (GA) content, and methoxyl (MeO) content of breadnut fruit pectin. The breadnut fruit pectin obtained in this study did not meet the quality requirements of IPPA, because of the GA content $<65 \%$, and also the quality requirements of USP 32 / Indonesian Pharmacopoeia 5th Edition, because of the GA content $<74 \%$ and the MeO content $<6.7 \%$.

\section{References}

[1] A. Rakhmanova, Z. A. Khan, R. Sharif, and X. Lü, "Meeting the requirements of halal gelatin : A mini review," MOJ Food Process. Technol., vol. 6, no. 6, pp. 477-482, 2018, doi: 10.15406/mojfpt.2018.06.00209.

[2] I. Jaswir et al., "Optimization of extraction process of plant-based gelatin replacer," Int. Food Res. J., vol. 23, no. 6, pp. 2519-2524, 2016.

[3] P. Srivastava and R. Malviya, "Sources of pectin, extraction and its applications in pharmaceutical industry - An overview," Indian J. Nat. Prod. Resour., vol. 2, no. 1, pp. 10-18, 2011.

[4] Y. M. Vianney, N. Amanda, K. Pieknell, C. W. Johan, and P. H. Hardjo, "Evaluation of the antioxidant and antibacterial activity of breadnut (Artocarpus camansi blanco) leaf extracts," Indian J. Nat. Prod. Resour., vol. 9, no. 2, pp. 151-159, 2018.

[5] V. Suryanti, T. Kusumaningsih, and Y. S. Rumingtyas, "Physicochemical Properties of Dietary Fibers from Artocarpus camansi Fruit," IOP Conf. Ser. Mater. Sci. Eng., vol. 193, no. 1, pp. 6-11, 2017, doi: 10.1088/1757-899X/193/1/012012.

[6] Y. Febriyanti, A. R. Razak, and N. K. Sumarni, "Ekstraksi dan Karakteristik Pektin Dari Kulit 
Buah Kluwih (Artcarpus camansi Blanco)," Kovalen, vol. 4, no. April, pp. 60-73, 2018, doi: 10.1590/0074-02760190033.14.

[7] E. H. Cho, H. T. Jung, B. H. Lee, H. S. Kim, J. K. Rhee, and S. H. Yoo, "Green process development for apple-peel pectin production by organic acid extraction," Carbohydr. Polym., vol. 204, pp. 97-103, 2019, doi: 10.1016/j.carbpol.2018.09.086.

[8] H. Mohamed, "Extraction and Characterization of Pectin from Grapefruit Peels," MOJ Food Process. Technol., vol. 2, no. 1, pp. 31-38, 2016, doi: 10.15406/mojfpt.2016.02.00029.

[9] C. M. Leong, M. A. Noranizan, M. Kharidah, and W. S. Choo, "Physicochemical properties of pectin extracted from jackfruit and chempedak fruit rinds using various acids," Int. Food Res. J., vol. 23, no. 3, pp. 973-978, 2016.

[10] M. Sarah, F. Hanum, M. Rizky, and M. F. Hisham, "Microwave-assisted extraction of pectin from cocoa peel," IOP Conf. Ser. Earth Environ. Sci., vol. 122, 2018, doi: 10.1088/17551315/122/1/012079.

[11] D. Li, G. Du, W. Jing, J. Li, J. Yan, and Z. Liu, "Combined effects of independent variables on yield and protein content of pectin extracted from sugar beet pulp by citric acid," Carbohydr. Polym., vol. 129, pp. 108-114, 2015, doi: 10.1016/j.carbpol.2015.04.058.

[12] I. Jaswir et al., "Optimization of extraction process of plant-based gelatin replacer," Int. Food Res. J., vol. 23, no. 6, pp. 2519-2524, 2016.

[13] R. Begum, M. G. Aziz, Y. A. Yusof, and M. Burhan, "Extraction and characterization of pectin from jackfruit ( Artocarpus heterophyllus Lam ) waste," IOSR J. Pharm. Biol. Sci., vol. 12, no. 6, pp. 42-49, 2017, doi: 10.9790/3008-1206044249.

[14] DIRJEN POM, Farmakope Indonesia, 5th ed. Jakarta: Departemen Kesehatan Republik Indonesia, 2014.

[15] U. Altaf, G. Immanuel, and F. Iftikhar, "EXTRACTION AND CHARACTERIZATION OF PECTIN DERIVED FROM PAPAYA,” Int. J. Sci. Eng. Technol., vol. 3, no. 4, pp. 970-974, 2015.

[16] R. Kumar, P. Chanalia, D. Gandhi, and S. Dhanda, "Optimized Extraction and Characterization of Pectin from Gooseberry and Strawberry Pomace Validated by Response Surface Methodology," World Appl. Sci. J., vol. 34, no. 6, pp. 704-713, 2016, doi: 10.5829/idosi.wasj.2016.34.6.30.

[17] R. Begum, M. G. Aziz, Y. A. Yusof, and M. Burhan, "Extraction and characterization of pectin from jackfruit ( Artocarpus heterophyllus Lam ) waste," vol. 12, no. 6, pp. 42-49, 2017, doi: 10.9790/3008-1206044249.

[18] W. Wang et al., "Ultrasound-assisted heating extraction of pectin from grapefruit peel: Optimization and comparison with the conventional method," Food Chem., vol. 178, pp. 106-114, 2015, doi: 10.1016/j.foodchem.2015.01.080.

[19] A. A. S. Raj, S. Rubila, R. Jayabalan, and T. V Ranganathan, "A Review on Pectin: Chemistry due to General Properties of Pectin and its Pharmaceutical Uses," vol. 1, no. 12, pp. 10-13, 2012, doi: 10.4172 /scientificreports.5.

[20] P. Kanmani, "Extraction and Analysis of Pectin from Citrus Peels: Augmenting the Yield from Citrus limon Using Statistical Experimental Design," Iran. J. energy Environ., vol. 5, no. 3, pp. 303-312, 2014, doi: 10.5829/idosi.ijee.2014.05.03.10.

[21] FAO JECFA, FAO JECFA Monographs: Combined Compendium of Food Additive Specifications, 19th ed. Rome, 2016.

[22] A. Mortensen et al., Re-evaluation of pectin (E 440i) and amidated pectin (E 440ii) as food additives, vol. 15, no. 7. 2017.

[23] R. C. Rowe, P. J. Sheskey, and M. E. Quinn, Handbook of Pharmaceutical Excipients, 6th ed. 
London: Pharmaceutical Press, 2009.

[24] R. Indriani, A. M. Legowo, and S. Susanti, "Characteristics of Pectin Isolated from Mango (Mangifera indica) and Watermelon (Citrullus vulgaris) Peel," J. Appl. Food Technol., vol. 4, no. 2, pp. 31-34, 2018, doi: 10.17728/jaft.42.

[25] F. Hanum, I. Menka, D. Kaban, and M. A. Tarigan, "Ekstraksi Pektin dari Kulit Buah Pisang Raja (Musa sapientum )," J. Tek. Kim. USU, Vol. 1, No. 2, vol. 1, no. 2, pp. 21-26, 2012.

[26] N. Wathoni et al., "Characterization and Antioxidant Activity of Pectin from Indonesian Mangosteen ( Garcinia mangostana L .) Rind," Heliyon, vol. 5, no. July, p. e02299, 2019, doi: 10.1016/j.heliyon.2019.e02299.

[27] B. M. N. Nguyen and T. Pirak, "Physicochemical properties and antioxidant activities of white dragon fruit peel pectin extracted with conventional and ultrasound- assisted extraction," Cogent Food Agric., vol. 5, no. 00, pp. 1-13, 2019, doi: 10.1080/23311932.2019.1633076.

[28] K. A. T. Castillo-Israel, S. F. Baguio, M. D. B. Diasanta, R. C. M. Lizardo, E. I. Dizon, and M. I. F. Mejico, "Extraction and characterization of pectin from Saba banana [Musa 'saba'(Musa acuminata x Musa balbisiana)] peel wastes: A preliminary study," Int. Food Res. J., vol. 22, no. 1, pp. 202-207, 2015.

[29] M. Chaliha, D. Williams, H. Smyth, and Y. Sultanbawa, "Extraction and characterization of a novel Terminalia pectin," Food Sci. Biotechnol., vol. 27, no. 1, pp. 65-71, 2018, doi: 10.1007/s10068-017-0201-4.

[30] M. Sandarani, “A Review : Different Extraction Techniques of Pectin," J. Pharmacogn. Nat. Prod., vol. 3, no. 3, pp. 1-5, 2017, doi: 10.4172/2472-0992.1000143.

[31] N. Maneerat, N. Tangsuphoom, and A. Nitithamyong, "Effect of extraction condition on properties of pectin from banana peels and its function as fat replacer in salad cream," J. Food Sci. Technol., vol. 54, no. 2, pp. 386-397, 2017, doi: 10.1007/s13197-016-2475-6.

[32] U. Einhorn-Stoll, H. Kastner, A. Urbisch, L. W. Kroh, and S. Drusch, "Thermal degradation of citrus pectin in low-moisture environment - Influence of acidic and alkaline pre-treatment," Food Hydrocoll., vol. 86, pp. 104-115, 2019, doi: 10.1016/j.foodhyd.2018.02.030.

[33] O. A. Fakayode and K. E. Abobi, "Optimization of oil and pectin extraction from orange (Citrus sinensis) peels: a response surface approach,” J. Anal. Sci. Technol., vol. 9, no. 1, 2018, doi: 10.1186/s40543-018-0151-3.

[34] F. A. de Moura, F. T. Macagnan, L. R. dos Santos, M. Bizzani, C. L. de Oliveira Petkowicz, and L. P. da Silva, "Characterization and physicochemical properties of pectins extracted from agroindustrial by-products," J. Food Sci. Technol., vol. 54, no. 10, pp. 3111-3117, 2017, doi: 10.1007/s13197-017-2747-9.

[35] S. Y. Chan and W. S. Choo, "Effect of extraction conditions on the yield and chemical properties of pectin from cocoa husks," Food Chem., vol. 141, no. 4, pp. 3752-3758, 2013, doi: 10.1016/j.foodchem.2013.06.097.

[36] A. A. Torkova et al., "Physicochemical and functional properties of Cucurbita maxima pumpkin pectin and commercial citrus and apple pectins: A comparative evaluation," PLoS One, vol. 13, no. 9, p. e0204261, Sep. 2018, [Online]. Available: https://doi.org/10.1371/journal.pone.0204261.

[37] V. Urias-orona, A. Rascón-chu, and J. Lizardi-mendoza, "A Novel Pectin Material : Extraction, Characterization and Gelling Properties," Int. J. Mol. Sci., vol. 11, pp. 3686-3695, 2010, doi: 10.3390/ijms11103686. 